УДК 351:338.482

https://doi.org/10.52507/2345-1106.2021-2.23

НАЛОГООБЛОЖЕНИЕ АГРАРНЫХ ПРЕДПРИЯТИЙ: ПРАКТИКА УКРАИНЫ И ЗАРУБЕЖНЫЕ ТРЕНДЫ

ПАРМАКЛИ Дмитрий, д.э.н., профессор Комратский государственный университет parmad741@mail.ru https://orcid.org/0000-0003-2002-6104

БАХЧИВАНЖИ Людмила, к.э.н., доцент кафедры маркетинга, предпринимательства и торговли, Одесский национальный технологический университет, Украина e-mail: 7462686@ukr.net https://orcid.org/0000-0001-8381-9684 
БАРБИНЯГРА Александр,

аспирант кафедры менеджмента, Одесский государственный аграрный университет, Украина

e-mail: ukragro-lider@ukr.net

https://orcid.org/0000-0002-8496-4223

\begin{abstract}
АННОТАЦИЯ
В статье освещена существующая практика налогообложения аграрных предприятий Украины, проанализированы размеры единого налога для сельскохозяйственных производителей в сравнении с суммой налога на прибыль для общей системы налогообложения. Освещены основные подходы к налогообложению аграрных товаропроизводителей в европейской практике. Рассмотрена возможность адаптации мирового опыта в поддержке сельского хозяйства ипредложения относительно совершенствования налогообложения аграрных предприятий Украины в контексте его дифференциации относительно размеров субъектов хозяйствования и специализации.
\end{abstract}

Ключевые слова: налогообложение аграрных предприятий, налоговая нагрузка, единый налог, специальный режим налогообложения, налог на добавленную стоимость.

\title{
TAXATION OF AGRICULTURAL ENTERPRISES: UKRAINE PRACTICE AND INTERNATIONAL TRENDS
}

\author{
PARMAKLI Dmitrii, \\ Dr. Hab., professor, \\ Komrat State University, Moldova \\ parmad741@mail.ru \\ https://orcid.org/0000-0003-2002-6104
}

BAKHCHIVANZHI Liudmila $\mathrm{PhD}$, Associate professor, Department of marketing, entrepreneurship and trade, Odessa National Technological University, Ukraine e-mail: 7462686@ukr.net https://orcid.org/0000-0001-8381-9684

BARBINYAGRA Alexandr Postgraduate Student, Department of Management, Odessa State Agrarian University, Ukraine e-mail: ukragro-lider@ukr.net https://orcid.org/0000-0002-8496-4223

\section{SUMMARY}

The article highlights the existing practice of taxation of agricultural enterprises in Ukraine, analyzes the size of the single tax for agricultural producers in comparison with the amount of tax for the general taxation system. The main approaches to the taxation of agricultural producers in European practice are highlighted. The world experience in supporting agriculture is considered. The proposals for improving the taxation of agricultural enterprises in Ukraine in the context of its differentiation in relation to the size of business entities are considered.

Key words: taxation of agricultural enterprises, tax burden, single tax, special taxation regime, value added tax.

Введение. Налогообложение аграрных предприятий - одна из сложнейших проблем, которые существуют в практике налогообложения Украины.

За все годы независимости Украины актуальность решения вопроса выбора оптимальной и эффективной налоговой системы в аграрном секторе не только не снизилась, но и нарастала, достигнув в последние годы наивысшего уровня остроты. Налоговая политика государства в последние годы не дает эффективно развиваться малым и средним сельскохозяйственным производителям, с каждым годом налоговая загрузка возрастает. Обострила проблему, и непоследовательная политика в отношении специального режима налогообложения добавленной стоимости (НДС). Не отрицая целесообразности специального режима налогообложения аграрных предприятий, целью которого на первоначальном этапе его внедрения было стимулирование развития реорганизованных в процессе аграрной и земельной реформы субъектов хозяйствования, следует отметить необходимость усовершенствования налогового механизма в аграрном секторе в соответствии с современными условиями экономической среды и факторами международного и глобального характера.

Анализ последних исследований и публикаций.Проблемам налогообложения и государственной поддержки сельского хозяйства 
Украины посвятили свои публикации Босенко А., Варченко А., Жук В., Лупенко Ю., Онегина В., Тулуш Л. и многие другие ученые.

В частности, Босенко А.В. анализирует совершенствование налоговых отношений в контексте повышения эффективности агропромышленного комплекса Украины [1]. Варченко А.Н. оценивает зарубежный опыт государственной поддержки сельскохозяйственного производства и направления его использования в отечественной практике [2], Жук В.Н. исследует состояние и развитие специальных режимов налогообложения аграрного бизнеса [3]. Онегина В. анализирует опыт государственной поддержки аграрного сектора в развитых странах [4].

Стратегические направления налогового регулирования развития аграрного сектора экономики Украины на период до 2020 года определили Ю.А. Лупенко и Л.Д. Тулуш [5, 6, 7, 8, 9]. Академиком Лупенко Ю.А. отмечается, что в настоящее время система налогообложения находится в условиях трансформации, фактически происходит переход от дотационностимулирующего к регулирующему механізму налогообложения и предлагается новая концептуальная модель налогообложения в отрасли: введение пониженной ставки НДС на отдельные виды сельскохозяйственной продукции [9].

Сравнительный анализ налоговых систем осуществлено Найдой А.В. и Дьяковой А.И., котрые не только охарактеризовали выявленные проблемы, но и оценили перспективы совершенствования налогообложения сельскохозяйственных товаропроизводителей [10].

Однако на сегодняшний день многие вопросы остаются недостаточно исследованными и требуют углубленного изучения. Вопрос о необходимости применения финансовой поддержки аграриев в рамках системы налогообложения продолжает вызывать дискуссию в научных кругах и требует дальнейшего обоснования.

Цель статьи - проанализировать современное состояние налогообложения аграрных предприятий Украины и предложить рекомендации по его усовершенствованию.

Результаты

исследования.

Размеры налогообложения аграрных предприятий Украины определяются в настоящее время в первую очередь таким фактором, как размеры землепользования. Это характеризует аграрный сектор как такой, что в значительной мере формирует налоговыйпотенциал, так как от площади сельскохозяйственных угодий и их плодородия зависит сумма налоговых платежем. По данным государственной службы статистики, площадь сельскохозяйственных угодий в абсолютном выражении составляет 42 млн. гектаров, или в относительном выражении 70 \% общего земельного фонда Украины. $78,9 \%$ сельскохозяйственных угодий - пахотные земли и многолетние насаждения, 13,0\% - пастбища, 8,4\% - сенокосы. Самая высокая доля пахотных земель расположена в степных районах (70-80\%) и лесостепной зоне. Пастбища сосредоточены, в основном, в Карпатах, на Полесье и в юго-восточных степных областях, сенокосы - в долинах рек лесной и лесостепной зон.

В целом аграрный сектор рассматривается в двух аспектах: как объект дополнительной государственной поддержки и как источник доходов для бюджета государства. Наибольшие поступления в государственный бюджет Украины обеспечивает налог на добавленную стоимость. Самый главный дискуссионный вопрос финансовой деятельности аграрных предприятий - состояние специального режима налога на добавленную стоимость. Специальный режим налогообложения в части налога на добавленную стоимость длительное время использовался как ключевой рычаг государственной финансовой поддержки развития сельского хозяйства и обеспечивал финансирование отрасли в условиях ограниченных возможностей бюджетов различных уровней [11].

До 2015 года включительно на специальный счет аграрных предприятий возвращалось $100 \%$ налога на добавленную стоимость. Соответствующие суммы средств, которые вносились на специальные счета, оставались в распоряжении аграрного предприятия для использования в производстве сельскохозяйственной продукции.

В 2016 г. механизм НДС для аграрного сектора изменился. С 1 января 2016 объем зачисления средств на специальные счета сельскохозяйственных предприятий стал дифференцированным в зависимости от вида деятельности: по операциям при поставке зерновых и технических культур - $15 \%$, продукции животноводства - $80 \%$, других сельскохозяйственных товаров и услуг - 50 \% [10, пункт 48]. С 1 марта 2018 г. было отменено возмещение НДС при экспорте семян подсолнечника, сои, рапса. Специальный режим налогообложения НДС для отечественных сельскохозяйственных производителей, который действовал с 1998 года, позволил до 2016 года стимулировать развитие АПК и украинского села.

Изменение специального режима НДС для аграрных предприятий привело к значительному уменьшению государственной поддержки сельскохозяйственных предприятий, а также к значительному усложнению администрирования этого налога и невозможности четкого распределения налогового кредита между тремя направлениями сельскохозяйственного производства: по операциям с зерновыми, и техническими культурами, с продукцией животноводства и подругимиоперациям.

В декабре 2020 года Верховная Рада снизила ставку НДС для аграрного сектора с 20\% до 14\% [13]. Ставку НДС в размере 14\% установили по операциям поставки и ввоза в Украину следующей сельхозпродукции: крупный рогатый скот в живой массе, свиньи живые, цельное молоко, пшеница, рожь, ячмень, овес, кукуруза, (соевые бобы, семена льна, семена сурепки и рапса, семена подсолнечника, семена и плоды прочих масличных культур, сахарная 
свекла. Принятое решение ставило целью снижение налоговой нагрузки на производителей сельхозпродукции, что, в свою очередь, должно позволить уменьшить стоимость сырья на сумму снижения НДС уже для перерабатывающих эту продукцию предприятий.

При этом рентабельность производства вышеназванных видов продукции и торговли ими должны остаться без изменений. В то же время перерабатывающие предприятия смогут сэкономить 6\% затрат во время закупки сырья за счет меньших налоговых обязательств производителя.

Решение о снижении ставки НДС до 14 \% также было призвано ликвидировать стимулы для оптимизации налоговых обязательств, так называемых «скруток», обеспечить детенизацию аграрного производства и дополнительные поступления в бюджет [13].

Однако уже в июле 2021 года ставка НДС 20\% возвращена на ввоз: живой массы крупного рогатого скота, свиней, овец, молока цельного, ржи, овса, семян льна, и плодов других масличных культур, сахарной свеклы [14].

Ключевой составляющей системы налогообложения аграрных предприятий до 2014 года был фиксированный сельскохозяйственный налог, но с 1 января 2015 года он переведен в группу единых налогов как единый налог 4-й группы. К этой группе относятся сельскохозяйственные товаропроизводители, у которых доля сельскохозяйственного производства в выручке превышает $75 \%$. В 2014 г. фиксированный сельскохозяйственный налог составлял $0,03-1 \%$ нормативно-денежной оценки 1 га земли в зависимости от вида угодий и региона. В 2015 году ставка фиксированного сельскохозяйственного налога составляла уже 0,09-3\%, тогда как, для сравнения, ставка единого налога для 4-й группы в 2016 -м составляла $0,16 \%$ - 5,4\% нормативноденежной оценки 1 га земли, а в 2017 - 2018 гг. ставки растут в соответственно с 0,95 до $6,33 \%$.

Аграриям удалось отстоять льготную систему налогообложения. Однако ставки налога выросли в расчете на 1 га (в процентах базы налогообложения). Максимально увеличена ставка для пашни, сенокосов и пастбищ - до 0,95, в то время как предыдущий размер ставки - 0,81 в 20160,45 - в 2015 году (табл. 1).

Таблица 1. Нормативная денежная оценка земли Раздельнянского природно-сельскохозяйственного района и ставки налога для расчета годовой суммы налога при упрощенной и общей системах налогообложения

\begin{tabular}{|c|c|c|c|}
\hline Показатели & 2015 г. & 2016 г. & $\begin{array}{r}2017 \text { - } 2020 \\
\text { гг. в среднем }\end{array}$ \\
\hline $\begin{array}{l}\text { Нормативнаяденежная оценка } 1 \text { га } \\
\text { земельного участка, грн.: } \\
\text {-пашня; }\end{array}$ & 28623,36 & 28623,36 & 28623,36 \\
\hline - пастбища; & 7595,63 & 7595,63 & 7595,63 \\
\hline -многолетние насаждения & 58459,98 & 58459,98 & 58459,98 \\
\hline $\begin{array}{l}\text { Ставка единого налога 4-й группыпо } \\
\text { видам земельных угодий (для упрощенной } \\
\text { системы налогообложения), \% } \\
\text {-пашня; }\end{array}$ & 0,45 & 0,81 & 0,95 \\
\hline - пастбища; & 0,45 & 0,81 & 0,95 \\
\hline - многолетние насаждения & 0,27 & 0,49 & 0,57 \\
\hline $\begin{array}{l}\text { Розмер налогаиз расчета на } 1 \text { га, грн. } \\
\text { - } \quad \text { пашня }\end{array}$ & 128,81 & 231,85 & 271,92 \\
\hline - пастбища & 34,18 & 61,52 & 72,16 \\
\hline - многолетние насаждения & 157,84 & 286,45 & 333,22 \\
\hline $\begin{array}{l}\text { Ставка налога на прибыль (при общей } \\
\text { системе налогообложения), \% }\end{array}$ & 18 & 18 & 18 \\
\hline
\end{tabular}

Следствием перехода от фиксированного сельскохозяйственного налога к единому налогу 4-й группы для аграрных товаропроизводителей и увеличения ставок единого налога 4-й группы стало не всегда выгодное применение варианта специального режима налогообложения аграрных предприятий по единому налогу 4-й группы. На этоуказывают расчеты, приведенные в таблице 2 на примере двух аграрных предприятий, характеризующихся различными финансовыми результатами деятельности и формой собственности: государственного предприятия опытного хозяйства им. Суворова и общества с ограниченной ответственностью «Заря».

Расчеты показывают, что для ГП ОХ им. Суворова более выгодной является общая система налогообложения, сумма налога на прибыль при которой составила бы 6660 грн. против 1 млн. 722 
тис.грн. при налогообложении единым налогом 4-й группы для аграрных товаропроизводителей. Причиной такого вывода является незначительная сумма чистой прибыли как объекта расчета налога на прибыль. Только тогда, когда сумма чистой прибыли составит 9568,573 тыс. грн., суммы единого налога и налога на прибыль сравняются. Но в ближайшей перспективе предприятие останется малоприбыльным, поэтому здесь выгоднее выбирать общую систему налогообложения и платить налог на прибыль.

Таблица 2. Расчет годовой суммы налога при упрощенной и общей системах налогообложения в аграрных предприятиях Раздельнянского района Одесской области

\begin{tabular}{|c|c|c|c|}
\hline Показатели & 2015 г. & 2016 г. & $\begin{array}{l}2017 \text { - } 2020 \text { гг. в } \\
\text { среднем }\end{array}$ \\
\hline \multicolumn{4}{|c|}{ ГП ОХ им. Суворова } \\
\hline Площадь пашни, га & 6245 & 6245 & 6245 \\
\hline $\begin{array}{l}\text { Площадь многолетних насаждений, } \\
\text { га }\end{array}$ & 36 & 36 & 36 \\
\hline Площадь пастбищ, га & 169 & 169 & 169 \\
\hline $\begin{array}{l}\text { Годовая сумма единого налога 4-й } \\
\text { группы, тыс. грн. (для упрощенной } \\
\text { системы налогообложения) }\end{array}$ & 815,847 & 1468,608 & 1722,343 \\
\hline Чистая прибыль, тыс. грн. & 50 & 60 & 37 \\
\hline $\begin{array}{l}\text { Годовая сумма налога на прибыль, } \\
\text { тыс. грн. (при условии общей системы } \\
\text { системы налогообложения) }\end{array}$ & 9,000 & 10,800 & 6,660 \\
\hline \multicolumn{4}{|c|}{ OОО «Заря» } \\
\hline Площадь пашни, га & 1884 & 1898 & 1898 \\
\hline Площадь сенокосов, га & 25 & 80 & 80 \\
\hline $\begin{array}{l}\text { Годовая сумма единого налога 4-й } \\
\text { группы, тыс. грн. (для упрощенной } \\
\text { системы налогообложения) }\end{array}$ & 243,523 & 444,972 & 521,880 \\
\hline Чистая прибыль, тыс. грн. & 4027 & 9331 & 12727 \\
\hline $\begin{array}{l}\text { Годовая сумма налога на прибыль, } \\
\text { тыс. грн. (при условии общей системы } \\
\text { системы налогообложения) }\end{array}$ & 724,860 & 1679,580 & 2290,860 \\
\hline
\end{tabular}

Источник: рассчитано авторами на основе данных данных финансовых отчетов предприятий

В ООО «Заря» ситуация противоположная. При фактической сумме чистой прибыли предприятию выгоднее платить единый налог. И только, когда сумма чистой прибыли составит 2899,336 тыс. грн. и меньше, экономически выгодным для предприятия станет использование общей системы налогообложения.

Таким образом, на данном этапе система налогообложения должна быть дифференцированной с учетом экономического и финансового состояния предприятий. Для низкорентабельных государственных предприятий целесообразно дать возможность выбирать обычную систему налогообложения. Для аграрных предприятий, являющихся субъектами малого предпринимательства, но которые получают значительные финансовые результаты, целесообразно оставить упрощенную систему налогообложения при условии реинвестиции прибыли. Так, ООО «Заря» за последние три года приобрело 2 зерноуборочных комбайна и трактор. Расширенное воспроизводство основних средств стало возможным, благодаря значительной экономии финансовых ресурсов на уплате единого налога по сравнению с той суммой, которую пришлось бы заплатить в качестве налога на прибыль при общей системе налогообложения.

Еще одно изменение в налогообложении аграрных предприятий касается земельного налога. До 2015 года от уплаты земельного налога освобождались: плательщики фиксированного сельскохозяйственного налога за земельные участки для ведения сельскохозяйственного товарного производства, вновь созданные фермерские хозяйства в течение трех лет, а в населенных пунктах, где нет рабочей силы, - в течение 5 лет с момента передачи им земельного участка в собственность. С 2016 предприятия АПК платят земельный налог на общих основаниях. Предельный размер ставки земельного налога за земли сельскохозяйственных угодий увеличен до 1\% от их нормативной денежной оценки, в то время как ранее он был - 0,1\% для пашни, сенокосов и пастбищ и $0,03 \%$ - для многолетних насаджений.

Бесспорно, использование упрощенной системы налогообложения в аграрном секторе Украины 
сыграло свою роль снижения налоговой загрузки для реформируемых предприятий, которые накануне реформы и реорганизации оказались без оборотного капитала, призванного обеспечить ритмичную работу предприятий. Однако в результате капитализации многие предприятия достигли значительных финансовых результатов и размеров деятельности. Поэтому значительная дифференциация аграрных предприятий по этим критериям требует и пересмотра налоговой политики в аграрном производстве. Система налогообложения аграрного бизнеса является одним из действенных инструментов (косвенного воздействия) финансового регулирования аграрного сектора экономики любой страны. Анализ публикаций по вопросам налогообложения сельского хозяйства в мире, проведенный в исследованиях Соколенко Л.Ф., показывает, что для многих стран мира система налогообложения имеет общие черты, такие как:

- наличие налоговых льгот,

местные,

- наличие гибкого, мобильного налогового механизма, способного быстро адаптироваться в условиях меняющейся экономической среды [15].

Ввиду того, что налоговые системы экономически развитых стран складывались не одно столетие под влиянием политических, социальноэкономических и других условий, для каждой из них характерны определенные особенности, которые отличают их по типу построения и составляющим налоговой системы.

Государственное регулирование сельского хозяйства за рубежом имеет ряд отличий. Оно включает в себя совокупность различных инструментов воздействия не только на доходы сельскохозяйственных товаропроизводителей, но и призвано регулировать такие важные составляющие аграрного рынка, как структура производства, социальная структура, межотраслевые и межхозяйственные отношения [3]. Среди приоритетных способов регулирования выделяют налоговое стимулирование, при этом важной составляющей является поддержка доходов производителей и компенсационные выплаты. Льготы по налогу на прибыль, применяются в странах ЕС, включают: дифференцированные ставки налогообложения, необлагаемые резервы, ускоренная амортизация, инвестиционная налоговая скидка, инвестиционный налоговый кредит, налоговые каникулы, упрощенный режим налогообложения.

Несмотря на то, что во всех ведущих странах экономических лидерах сельское хозяйство облагается, как и другие сектора экономики, льготное налогообложение является одним из факторов, позволяющих успешно функционировать сельскому хозяйству. Товаропроизводителям предоставляется большой перечень налоговых льгот в рамках основного налогового режима, а также предусматривается особый режим налогообложения, обоснованный сезонностью сельскохозяйственного производства, зависимостью от природных условий, финансовым состоянием и показателями эффективности деятельности сельскохозяйственных организаций.

Заслуживает изучения опыт Канады, где ставка налога варьирует по провинциям. Земельный налог в стране относится к местным налогам и сборам. При оценке земель сельхозпредприятий учитываются такие факторы, как форма использования, рельеф местности, плодородие и наличие инфраструктуры. С учетом того, что Правительством Канады поставлена цель максимально снизить налоговое бремя фермеров, балансовая стоимость земель сельскохозяйственного назначения оценивается по минимальному уровню. В целом государственная поддержка аграриев в Канаде привязана к «пятилеткам» - Пятилетним стратегическим планам развития. С 2018 года в стране действует «Канадское сельскохозяйственное партнерство: 2018-2023». Этим глобальным документом предусмотрен целый ряд программ поддержки (многие из которых действовали и ранее) в шести приоритетных областях.

В странах Центральной и Восточной Европы налогообложение земель четко дифференцировано в зависимости от качества земель, широко используются кадастровые оценки при установлении налога за отвод сельскохозяйственных земель для несельскохозяйственных потребностей. В Болгарии с конца 80 гг. применяются дифференцированные ставки земельного налога, с некоторыми корректировками они действуют в настоящее время. Пахотные земли разделены на 11 групп по их качеству с разными ставками земельного налога, отличающимися по крайним группам в 4 раза.

Для Украины целесообразным для изучения и внедрения является опыт стран, где используется дифференцированный поход к налогообложению аграрных предприятий, ввиду многоукладности сельского хазяйства, которая определяется разнооброазием форм собственности и организационно-правовых форм.

В ряде стран используется дифференциация налогообложения как по субъектам предпринимательской деятельности АПК, так и по отраслям. Так, в США, где отсутствуют льготные ставки налога на доходы, действует прорессивная шкала налогообложения и доходы фермеров облагаются по наименьшим ставкам. Вместе с тем аграриям США предоставляют другие льготы, в частности, они могут использовать отчисления, уменьшать налогооблагаемую базу на сумму страховых взносов. Кроме того, существует возможность исчисления налога в среднем за три года. Аналогичная система отчислений по подоходному налогу фермеров действует и во Франции. При расчете налога на доходы из налогооблагаемой базы могут вычитаться страховые взносы, проценты по займам на строительство жилья и другие. В результате доходы фермеров подлежат обложению на суммы, значительно меньшие 
среднего по экономике уровня. Кроме того, во Франции активно используется сельскохозяйственный налог для проведения социальной политики. Выражается это в том, что в стране существует три режима налогообложения для сельского хозяйства, которые используются в зависимости от уровня дохода сельхозтоваропроизводителей, чем меньше их размеры и ниже доходы, тем больше налоговых льгот они получают. Аналогично разделение сельскохозяйственных предприятий на 3 группы представлены в Германии, где товаропроизводителям с низким уровнем дохода также предоставляются льготы.

Изучение опыта дифференциации налогообложения в Европе свидетельствует о наличии целого ряда инструментов снижения налоговой нагрузки в отдельных отрасляхсельского хазяйства. Так, ряд льгот и более низких ставок предусмотрены для конкретных видов экономической деятельности: молочного скотоводства, овощеводства, садоводства, переработки продукции сельского хазяйства, что позволяет влиять на уровень развития этих отраслей. Подобная практика может быть целиком оправданной и в Украине в отношении, например, молочного животноводства, что могло бы положительно повлиять на его возрождение в общественном хозяйстве.

Особого изучения требует вопрос о налогообложении государственных аграрных предприяий, среди которых сегодня преобладают исследовательские и опытные хазяйства научноисследовательских центров Академии аграрных наук Украины. На эти предприятия розложена важная стратегическая миссия в осуществлении аграрной политики в эпоху глобальних вызовов и изменений климата, связанная с выведением и испытанием сортов сельскохозяйственных культур, адаптированных к новым климатическим условиям. Конечный результат деятельности этих предприятий - наукоемкая продукция, от качества и себестоимости которой зависит эффективность деяльности всех предприятий АПК. Сегодня эти государственные предприятия, как правило, низкорентабельны, что не позволяет им обеспечивать расширенное воспроизводство основного капитала и формировать современную экспериментальную производственную инфраструктуру, о чем свидетельствует пример исследуемого государственного предприятия ОХ им. Суворова Раздельнянского района Одесской области. Финансовое состояние таких стратегических для аграрного сектора предприятий требует государственной поддержки, в том числе и в контексте применения специального режима налогообложения. Ввиду того, что удельный вес налоговых отчислений этих предприятий от поступлений всех предприятий аграрного сектора незначителен, целесообразно было бы освободить на 5 лет эти предприятия от уплаты единого налога. Это позволило бы мобилизировать значительные суммы финансовых ресурсов для модернизации производства, оптимизации структуры капитала, диверсификации источников капитальных вложений, привлечения высококвалифицированных научных кадров. В последующий период целесообразно перевести эти предприятия, теперь уже характеризующиеся экономической и финансовой стабильностью, в группу плательщиков налогов в рамках общей системы налогообложения, дифференцировав ставки налога на прибыль в зависимости от уровня рентабельности.

Выводы. Обобщая накопленный в ходе аграрной, земельной и налоговой реформ опыт налогообложения аграрных товаропроизводителей в Украине, и, рассматривая целесообразность имплементации мирового и европейского опыта, следует сделать вывод, что для аграрного сектора экономики на данном этапе наиболее эффективным следует считать подход, основанный на дифференциации налогово-финансовых инструментов относительно размеров предприятий и их специализации.

Практика специального режима налогообложенния, предусматривавшая уплату фиксированного сельскохозяйственного налога и аккумулирование НДС на специальных счетах предприятий с целью поддержки развития аграрного производства достигла цели в контексте снижения налоговой нагрузки и предоставления возможности значительному количеству аграрных предприятияй сформировать достаточный запас ресурсного и финансового потенциала. Однако многоукладность аграрной экономики и значительная дифференциация предприятий по размерам хозяйствования и финансовым результатам требует соответствующей дифференциации подходов в налогообложении.

Целесообразно пол размерам предприятий, придерживаясь их классификации на такие группы:

1. микропредприятия (фермерские хозяйства, основанные на применении труда их членов и членов семьи фермера) с уплатой единого налога, который включает и НДС с аккумулированием на специальных счетах с целью использования его на развитие хозяйства;

2. малые и средние субъекты хозяйствования (юридические лица различных организационноправовых форм) с предоставлением права выбора единого налога или общей системы налогообложения;

3. крупные и макропредприятия, включая агрохолдинги, землепользование которых размещено на территории нескольких административнотерриториальных единиц с общей системой налогообложения и дифференциацией ставки налога на прибыль в зависимости от размера налогооблагаемой прибыли или уровня рентабельности.

Такой подход следует считать формой государственной поддержки становлення фермерских хазяйств и малых субъектов 
хозяйствования. К числу критериев определения размеров предприятия в аграрном секторе кроме трех используемых (балансовая стоимость активов, среднегодовая численность работников и размер дохода от реализации) включить и размеры землепользования.

В рамках первых двух групп предприятий по размерам хозяйствования предлагается выделить две подгруппы:

1. Предприятия, специализирующиеся на производстве продукции растениеводства;

2.Смешанные предприятия, в которых не менее $50 \%$ дохода от реализации составляет продукция животноводства.

Для предприятий второй подгруппы предлагается использовать более низкие ставки единого налога и сохранение практики аккумулирования НДС на специальных счетах с целью поддержки развития и стимулирования возрождения животноводства.

В отдельную группу предлагается выделить государственные предприятия - опытные хозяйства научно-исследовательских центров, разработав для них специальный режим налогообложения с учетом стратегического значения этих предприятий для аграрного сектора.

Такой дифференцированный подход позволит поддержать развитие многоукладной экономики аграрного сектора, решить ряд социальных проблем сельских территорий и обеспечить конкуретспособность фермерских хозяйств, малых и средних субъектов хозяйствования как частной, так и государственной форм собственности

\section{Библиографические сноски:}

1. Босенко А.В Удосконалення податкових відносин i підвищення ефективності АПК. Вісник Дніпропетровського університету. Серія «Економіка». Вип. 5(3). 2011. с.87 - 94.

2. Варченко О. Зарубіжний досвід державної підтримки сільськогосподарського виробництва та напрями його використання у вітчизняній практиці. Економіка та управління АПК: Збірник наукових праць. Білоцерків. нац. аграр. ун-т. Біла Церква, 2011. Вип. 5 (85). С. 11-16.

3. Жук В. Стан і розвиток спеціальних режимів оподаткування аграрного бізнесу. Фінанси України. № 7. 2011- c. $33-42$.

4. Онєгіна В. Зміна аграрної парадигми та державна аграрна політика у розвинутих країнах. Економіка України. 2005. № 11. с. 62-72.

5. Лупенко Ю.О., Тулуш Л.Д. Стратегічні напрями податкового регулювання розвитку аграрного сектора економіки України на період до 2020 року. К.: ННЦ IAE, 2014. - 36 с.

6. Лупенко Ю.О., Тулуш Л.Д. Оподаткування сільського господарства в умовах трансформації спеціальних податкових режимів. Економіка АПК. - 2016. - № 1 - С. 5-17

7. Lupenko Yu. Special taxation modes in the Ukrainian agricultural sector / Yu. Lupenko, L. Tulush // The CAP and competitiveness of the Polish and European food sectors. - Editors A.Kowalski, M. Wigier, B. Wieliczko. - Institute of agricultural and food economics, Nation research institute. - Warsaw, 2014. - P. 106-117.

8. Тулуш Л.Д. Режим ПДВ-акумуляції як інструмент фіскального стимулювання розвитку агропромислового виробництва. Економіка АПК. 2015. - № 8. - С. 44- 55.

9. Лупенко Ю.О. Моделювання соціально-економічних відносин процесі наукових досліджень. Економіка АПК, 2018, № 2, с. 5-13.

10. Найда А.В., Д'якова А.І. Оподаткування сільськогосподарських товаровиробників: проблеми та перспективи. Аграрний вісник Причорномор'я. Збірник наукових праць. Економічні науки. Випуск 86.Одеса. 2017. C. 111-116.

11. Відмовлятися від спецрежиму оподаткування ПДВ для сільського господарства в сучасних умовах недоцільно - Інститут аграрної економіки. URL: http://www.iae.org.ua/presscentre/presrelease/711-2014-04-29-1156-40.html. (дата обращеия 25.08.2021).

12. Закон України "Про внесення змін до Податкового кодексу України та деяких законодавчих актів України щодо забезпечення збалансованості бюджетних надходжень у 2016 році" від 24 грудня 2015 року № 909 VIII URL: https://zakon.rada.gov.ua/laws/show/909-19. (дата обращеия 28.08.2021).

13. ПДВ для аграріїв зменшили до 14\%. https://finclub.net/ua/news/pdv-dlia-ahrariiv-zmenshyly-do14protsent.html. (дата обращеия 12.09.2021).

14. Про внесення змін до Податкового кодексу України щодо ставки податку на додану вартість при оподаткуванні операцій з постачання окремих видів сільськогосподарської продукції. Закон України №5425д.URL: Agravery.com.

15. Соколенко Л. Ф. Зарубіжний досвід оподаткування аграрного сектора економіки. Бізнес Інформ. - 2017. - № 4. - C. 55-60. -URL: http://nbuv.gov.ua/UJRN/binf_2017_4_9 . (дата обращеия 15.08.2021). 